\title{
Different Manifestation of Brucellosis in Pregnancy: Case Reports
}

\author{
Jila Agah1, Reza Jafarzadeh Esfehani², Batool Kamalimanesh² \\ ${ }^{1}$ Department of Obstetrics \& Gynecology, Faculty of Medicine, Sabzevar University of Medical Sciences, Sabzevar, Iran \\ ${ }^{2}$ Student Research Committee, Sabzevar University of Medical Sciences, Sabzevar, Iran
}

\begin{abstract}
Brucellosis is a zoonotic disease which is endemic in some areas of Iran. The most common symptoms of brucellosis are fever, nightly sweating, chilling, myalgia, fatigue, back pain and arthralgia. Its misdiagnosis can lead to chronic psychological, physical and socioeconomical harms. Mismanagement of infected pregnant women can jeopardize both maternal and fetal safety as well. In this paper we will discuss brucellosis in 5 pregnant women who revealed different manifestations. Surprisingly, none of them had showed fever but it had become apparent after spontaneous abortion. As pregnancy could be accompanied with symptoms like sweating and back pain, the symptoms of brucellosis had been attributed to normal pregnancy and resulted in diagnosis delay. So the unspecific signs and symptoms of involved cases in second or third trimester could not guide the patients or physicians to diagnose brucellosis promptly which resulted in its prolongation, misdiagnosis and mismanagement. J Microbiol Infect Dis 2016;6(2): 80-83
\end{abstract}

Key words: Brucellosis, fever, pregnant women, misdiagnosis.

\section{Gebelikte Brusellozun Farklı Görünümleri: Vaka Sunumları}

\section{ÖZET}

Bruselloz İran'ın bazı bölgelerinde endemik olan bir zoonotik hastalıktır. Brusellozun en sık görülen semptomları ateş, gece terlemesi, titreme, kas ağrısı, yorgunluk, sırtta ağrı ve eklem ağrısıdır. Yanlış tanı konulması kronik psikolojik, fiziksel ve sosyoekonomik zararlara yol açar. Enfekte gebe kadınların düzgün tedavi edilmemesi anne ve cenini tehlikeye atabilir. Bu yazıda farklı tezahürlerle seyreden brusellozlu beş gebe irdelendi. İlginç bir şekilde gebelerden hiçbirinde ateş bulgusu yoktu, ancak kendiliğinden olan düşük sonrasında ortaya çıktı. Terleme ve sırt ağrısı gibi semptomlar normal gebelik semptomlarına atfedilerek gebelikteki brusellozun tanısında gecikmelere yol açabilir. Spesifik olmayan bulgular ve semptomlar ikinci ve üçüncü üç aylık dönemde hastalar ve hekimler için brusellozun hızlı tanısında yol göstermez ve bu durum tanı ve tedavinin uzamasına, yanlış tanı ve tedaviye yol açabilir.

Anahtar kelimeler: Bruselloz, ateş, gebe kadınlar, tanıda yanlışlık

\section{INTRODUCTION}

Approximately 500,000 people are becoming infected by brucellosis annually. In spite of its prevalence, it has become one of the most neglected bacterial tropical diseases in Middle East and North Africa $[1,2]$. This zoonotic disease has also become an endemic disease in Iran and brought many significant health and socioeconomic problems [3]. The transmission of infection is mainly through direct contact with farm animal birth products, milk ingestion or aerosols inhalation. An epidemiological study in north of Iran showed that approximately $60 \%$ of patients with brucellosis were from rural areas [4]. The most human etiologic factor of this bacterial disease is Brucella melitensis [4,5]. Bacterial isolation is the gold standard for diagnosis of brucellosis [2], but it is often unsuccessful or has long cultivation period. Therefore serologic tests which are available and inexpensive are applied now. Wright and 2-mercaptoethanol (2ME) tests are commonly used in our country.

The most common symptoms of brocellosis are fever, nightly sweating, chilling, myalgia, fatigue, back pain and arthralgia [4,5]. In 2003, Sabzevar was found the highest rate of brucellosis in Iran [6] 
The incidence of brucellosis in pregnancy varies widely in different regions and is not clearly evaluated in our country $[7,8]$. Presence of broad range of unspecific symptoms can delay the diagnosis and treatment of this illness and lead to chronic psychological, physical and also socioeconomical harms [9]. It seems that in some situations like pregnancy the diagnosis retardness is more prevalent. In this report we will discuss five cases of brucellosis during pregnancy with atypical manifestations and their outcomes.

\section{Cases}

\section{Case 1}

A 29 year old rural woman with 8 weeks of gestational age referred to our clinic because of painless vaginal bleeding with symptoms of partial abortion and underwent curettage, and then she was discharged in a healthy condition. Ten days later, she referred in a febrile status associated with chilling. According to the positive history of using unpasteurized dairy products as well as having close contact with farm animal in their house, the brucellosis infection was suspected. Further management showed Wright and $2 \mathrm{ME}$ titer of $1: 1280$ and 1:40 respectively (diagnostic range Wright $\geq 1: 80,2 \mathrm{ME} \geq 1: 40$ ) erythrocyte sedimentation rate $(E S R): 35 \mathrm{~mm} / \mathrm{h}$. Past history and acute start of signs revealed acute brucellosis. The patient was treated with doxycycline $(100 \mathrm{mg}$ oral twice daily) and rifampicin (300 mg oral twice daily) for 8 weeks with intramuscular streptomycin (1 gr intramuscular) for the first 14 days. After the termination of the treatment, the serologic results fell down (Wright= 1/160, 2ME=1/40).

\section{Case 2}

A 31 year old rural 6 weeks pregnant woman referred to gynecologic clinic because of vaginal bleeding while sonography confirmed complete abortion. She had been treated 6 months ago for brucellosis with rifampicin (300 $\mathrm{mg}$ oral twice daily) and co-trimoxazole $(800 \mathrm{mg})$ for 8 weeks. Whereas she had no complaint of fever or chilling while reffering to clinic and was discharged immediately. One week later, the patient referred to gynecologic clinic with chilling fever, night sweating and low back pain similar to previous symptoms. Laboratory findings showed Wright 1:160 and 2ME titers 1:40. The patient was treated like the first episode of disease.

\section{Case 3}

A 36 year old rural 19 weeks pregnant women referred to clinic with vaginal spotting and foully discharge while fetal heart rate was not detectable by sonography. So she was underwent induced labor. Based on patient's declaration she had been suffered from shaking chills without fever and day time sweating from 2 months gestation of age and has been treated by diagnosis of acute brucellosis till now (Wright and 2ME titers were 1:320 and 1:80 at the beginning of diagnosis and 1:80 and 1:40 now respectively). In spite of appropriate treatment for brucellosis, the pregnancy had been failed. She declared that many people suffered from brucellosis in her village in recent months. She had been treated with rifampicin $(600 \mathrm{mg})$ and co-trimoxazole (800 $\mathrm{mg}$ ).

\section{Case 4}

A 36 year old rural 27 weeks pregnant woman was referred to obstetrics clinic because of long-term backache. She had been managed with pain killers which had no response for two months. While she had no complaint of fever and chilling symptoms were attributed to physiologic pregnancy symptoms. She was hospitalized because of malaise and aggravation of her backache. Her more complete past history showed the site of living in a husbandry region and sweating. So, the brucellosis and other laboratory tests (white blood cell count (CBC), polymorphonuclear leukocytes (PMN) 64\%, Widal test negative, rheumatoid factor (RF) negative, $E S R \geq 50$ $\mathrm{mm} / \mathrm{h}$ ) were ordered. Wright and $2 \mathrm{ME}$ titers were $1: 640$ and 1:320 respectively. The patient treatment regimen was as same as third case. She gave vaginal birth to a 3.2 kilogram healthy male baby at term.

\section{Case 5}

A 32 year old 26 weeks pregnant woman admitted in obstetric service because of right shoulder pain associated with sweating without fever from 10 weeks. There was also a history of similar symptoms one year ago which was treated as brucellosis infection with rifampicin (600 $\mathrm{mg}$ ) and co-trimoxazole $(800 \mathrm{mg})$. While the patient was worried about her brucellosis flare up, she had taken laboratory tests. Wright and 2 ME titers were 1:320 and 1:160 respectively. The patient was treated as the third case. She delivered a healthy 2700 gram female baby at 37 weeks of gestation. 


\section{DISCUSSION}

The average incidence of brucellosis has been reported as 43.24 per 100,000 people [10]. Fever, chilling, sweating and musculoskeletal disturbances are the most common symptoms. In most severe cases anemia, endocarditis, meningitis, pancytopenia and spondylitis may be appeared [9]. Dean et al. in a systemic review reported various manifestations of brucellosis in different populations like children [11]. We noticed that in pregnant patients the complaints are different as well; none of our cases declared fever as a prominent sign and only one of them stated chilling during pregnancy. Surprisingly, fever could become prominent after pregnancy termination. On the other hand their musculoskeletal pain or sweating had been attributed to physiologic changes of pregnancy which had led to neglected brusellosis. Sometimes the patient had been suffered from this disease for months.

After diagnosis of brucellosis, discussing the effects of this zoonotic disease on pregnant women will be the next step. Intrauterine infection with intrauterine fetal death (IUFD), spontaneous abortion and premature delivery are described among pregnant women with clinical brucellosis [12]. There are different symptoms of infection in each trimester of pregnancy. Among pregnant women with brucellosis, the incidence of and spontaneous abortion is between $31-46 \%$ [13]. While vaginal bleeding with or without fever is prevalent in the first trimester, febrile illnesses at term or post-partum is common in the third trimester [7]. Researches in north regions of Iran showed $55 \%$ of infections in pregnant women were in the first trimester and abortion had been accured before treatment of brucellosis in half of them [14]. Previous studies demonstrated that pregnant women with active brucellosis in the first and second trimester have higher rates of spontaneous abortion while brucella bacteremia or serum agglutinin titer do not have direct correlation with abortion rate [7]. On the other hand, Elshamy et al. found a significant difference between a titer more than $1 / 160$ and less than $1 / 160$ in term of abortion rate [8]. Screening programs for pregnant women and those with spontaneous abortion should be considered in endemic areas [14]. In some cases oligohydramnios following sweating and arthralgia might be symptoms of brucellosis in pregnant women and these women should be screened [15]. Women with threatened abortion due to chronic brucellosis can have normal deliveries if they get appropriate treatment [14].
There are different regimens for treating brucellosis in pregnant women. Treating with co-trimoxazole and rifampicin can be used in pregnant women with brucellosis [13]. Co-trimoxazole plus rifampicin are protective against abortion [7]. In Roushan et al. study, co-trimoxazole plus rifampicin regimen lead to full term delivery in $69 \%$ of their population [14]. Although in some reports whether infected mothers get treatment or not, this infection may influence pregnancy outcomes and even be transmitted perinataly. In some of our cases, the related medication led to successful delivery.

Certainly, in time diagnosis of brocellosis can diminish physical and psychological disturbances of mother and also adverse obstetrical oucomes. Indeed, in pregnant women who are infected with brucellosis, the only way to achieve successful delivery could be prompt and appropriate approach. Unreasonable sweating as well as not responding pains in endemic areas should be evaluated for brucellosis infection in pregnant women. So, educating women and also health providers about risk factors of brucellosis and its unspecific symptoms could be very beneficial for prevention its adverse obstetric outcomes. Thinking of this disease especially in endemic regions is the critical point for prevention of its misdiagnosis and mismanagement.

\section{Acknowledgements}

The authors declare their appreciation from participants of this study.

Declaration of Conflicting Interests: The authors declare that they have no conflict of interest.

Financial Disclosure: No financial support was received.

\section{REFERENCES}

1. Hotez PJ, Savioli L, Fenwick A. Neglected tropical diseases of the Middle East and North Africa: Review of their prevalence, distribution, and opportunities for control. PLoSNegl Trop Dis 2012;6:e1475.

2. Gwida M, Al Dahouk S, Melzer F, et al. Brucellosis - regionally emerging zoonotic disease? Croat Med J 2010; 51:289-295

3. Kassiri $\mathrm{H}$, Amani $\mathrm{H}$, Lotfi M. Epidemiological, laboratory, diagnostic and public health aspects of human brucellosis in western Iran. Asian Pac J Trop Biomed 2013;3:589-594.

4. Roushan MR, Mohrez M, SmailnejadGangi SM, et al. Epidemiological features and clinical manifestations in 469 adult patients with brucellosis in Babol, Northern Iran. Epidemiol Infect 2004;132:1109-1114.

5. Sofian M, Aghakhani A, Velayati AA, Banifazl M, Eslamifar A, Ramezani A. Risk factors for human brucellosis in Iran: a case—control study. Int J Infect Dis 2008; 12:157-161. 
6. Azizi F, Hatami H, Janghorbani M. Epidemiology and control of common diseases in Iran. $4^{\text {th }}$ ed. Tehran: Khosravi Publications; 2010, p.915.

7. Khan YM, Mah MW, Memish ZA. Brucellosis in Pregnant Women. Clin Infect Dis 2001;32:1172-1177.

8. Elshamy M, Ahmed Al. The effects of maternal brucellosis on pregnancy outcome. J Infect Dev Ctries 2008;2:230-234.

9. Sauret JM, Vilissova N. Human Brucellosis. J Am Board Fam Pract 2002; 15:401-406.

10. Mostafavi E, Asmand M. Trend of brucellosis in Iran from 1991 to 2008. Iranian J Epidemiol 2012; 8:94-101.

11. Dean AS, Crump L, Greter H, Hattendorf J, Schelling E, Zinsstag J. Clinical manifestations of human brucellosis: a sys- tematic review and meta-analysis. PLoS Negl Trop Dis 2012; 6:e1929.

12. Solera J. Update on brucellosis: therapeutic challenges. Int J Antimicrob Agents 2010; 36 Suppl 1:S18-20.

13. Al-Tawfiq JA, Memish ZA. Pregnancy Associated Brucellosis. Recent Pat Antiinfect Drug Discov 2013; 8:47-50

14. Roushan MR, Baiani M, Asnafi N, Saedi F. Outcomes of 19 pregnant women with brucellosis in Babol, northern Iran. Trans R Soc Trop Med Hyg 2011;105:540-542.

15. Aydın B, Beken S, Akansel R, et al. Prematurity due to maternal brucella infection and review of the literature. Turk $J$ Pediatr 2013; 55:433-437. 